\title{
Deconstruction of the Welfare State: The Impact of Globalization and Technological Factors
}

\author{
NATALIYA KHOMA* \\ IHOR VDOVYCHYN \\ Institute of Philosophy \\ Department of Theory and History of Political Science \\ Ivan Franko National University of Lviv \\ Lviv, Ukraine
}

\author{
Review paper \\ UDK: $364.013: 327$ \\ doi: 10.3935/rsp.v27i3.1696
}

Received: January 2020

The article aims to investigate the processes of deconstruction of the institution of the welfare state under the influence of such new challenges as economic globalization and technological revolution. The study is based on the methodological tools of neo-institutionalism. Principal exogenous and endogenous reasons for the crisis of the welfare state institution are determined. Economic globalization and technological progress are designated as decisive factors conditioning the deconstruction of the welfare state. It is stated that irrespective of the welfare state model, nowadays they all are reformed towards the activation of a working-age person and the establishment of the state of social investments. Currently the configuration of the welfare state is specified by its commitment to stimulating competition and developing the self-initiative of citizens in terms of ensuring their own prosperity. It is highlighted that economic globalization and technological progress should not be considered exclusively from the standpoint of risks for the welfare state. These two factors are identified as stimuli for further evolution of the welfare state institution for the sake of its moving out of prolonged stagnation and preserving itself as a political institution, albeit in the upgraded model.

Key words: welfare state institution, deconstruction of the welfare state, economic globalization, platform economy, technological progress, Industry 4.0.

\section{INTRODUCTION}

Nowadays the welfare state institution is at the stage of a prolonged crisis, which has been increasing for almost half a century. The second default of the dollar (1971) and the first oil (energy) crisis (1973-1975) became the starting points of this process.
The welfare state has faced a complex of challenges: some of them are exogenous and are conditioned by strengthening of international interdependence; others are endogenous and are conditioned by internal social demographic, economic and political factors. In our estimation, the most

\footnotetext{
* Nataliya Khoma, Institute of Philosophy, Department of Theory and History of Political Science, Ivan Franko National University of Lviv, Universytetska Str. 1, aud. 316, Lviv 79000, Ukraine, nataliya.khoma@1nu.edu.ua
} 
important of them are economic globalization, technological progress, demographic disbalance, etc., to which the welfare state is not adapted in its current configuration. Since the first crisis phenomena in the functioning of the welfare state, there have been discussions concerning their causes and the ways of coming out of them.

Historically, the welfare state was the institutional basis for the management of inequalities which were triggered by the market functioning. The principal idea of the welfare state was to provide the security needed by people in the face of various risks that were associated with health, job loss, aging and other social risks. However, the functioning of that institution resulted in the opposite effect more and more frequently. The policy of the developed countries demonstrates how once generous welfare benefits are ousted by austerity policy.

Starting from the 1980s, the welfare state institution has been demonstrating the inability to adjust to current needs and challenges, while providing the essential elements of social support. Consequently, numerous social programs are ineffective in practice. At present, common global tendencies are the reduction in welfare benefits, the decrease in social services, the rise of the retirement age, etc. The deconstruction of the welfare state started as a reaction to its crisis.

Regardless of the welfare state model under introduction, they all face common challenges: increase in social spending, growing inequality, need for severe budget savings, etc. The technological revolution enhances economic vulnerability and various forms of inequality, and the value of a citizen is more frequently determined exclusively by his or her importance as an employee and a taxpayer. On the one hand, the complex of problems conditions the reduction in social benefits, the decrease in the volume of offered social services, the rise of the retirement age, and on the other - the activation of populists, general radicalization of politics, deformation of liberal democracy towards non-liberal democracy, etc. The aforementioned processes were reinforced with the global financial crisis, which started in 2008, and the European migration crisis of 2015. It is evident that welfare states in their present-day configuration are too expensive and cumbersome systems. The crisis of the welfare state is accompanied by debt and fiscal problems, rise in unemployment, mass street protests with demands that the states should maintain social standards, etc. We have drifted towards a "grey welfare state" where the interests of the elderly dominate (Kelly, 2018). This fact is justified by a constant decrease in allowances for working-age, low-income families in recent years, while expenses on pensioners are steadily growing. Therefore, in recent decades we have observed a gradual deconstruction of the welfare state as a response to its prolonged crisis.

Nowadays, there is an established consensus with regard to the need to change the political design of the welfare state institution which has entered a serious existential crisis. The issue of determining the prospects of this unstable institution and creating a new architecture of welfare is made actual. The trajectory of welfare state evolution with the consideration of changes, which were caused by economic globalization, Industry 4.0, aging of the population, changes in the labour market, migration crises, etc., needs to be reinterpreted. This poses the question of the impact of platform economy, non-standard workplaces, self-employment, freelance, etc. on the welfare state functioning.

New issues are currently focused on in the discussion about the prospects of the welfare state. What should be in the core of a new social model - social inclusion or social exclusion, or probably the third 
(compromise) variant? Will this updated model of the welfare state defend the interests of all or only of the most needy? Will the new model be aimed at reaching high living standards or will it choose to be a variant of the system that ensures only the minimal level of individual and collective security?

The content of the welfare state is acquiring its new configuration: it is granted the functions of stimulating competition, developing the self-initiative of citizens in terms of ensuring their own prosperity, supporting social partnership, etc. The alternatives to classic models of the welfare state are initially aimed at activating a person, at social investing into a person. The concept of social investment is becoming increasingly important (Hemerijck, 2017). Therefore, a transformation of the welfare state provides for a transition from the traditional policy of substituting income (retirement insurance, unemployment insurance program, etc.) to the activating of a working-age person in the labour market, creating the widest possible conditions for everyone's self-realization, limiting state expenses, etc. However, we can see that current policy of social investing has not been able to oust the traditional compensatory social protection.

Therefore, our goal is to substantiate the deconstruction of the institution of the welfare state under the influence of the newest challenges such as economic globalization and technological revolution. In addition, we emphasize that the list of factors that determine the deconstruction of the welfare state is not limited to these two. It is now clear that the COVID-19 pandemic and protracted quarantine measures will have a strong destructive impact on the institution of the welfare state in the near future, and subsequently this issue will need to be studied in depth.

\section{THE SYSTEM OF FACTORS ENHANCING THE CRISIS OF THE WELFARE STATE AND ITS CONSEQUENCES}

At present, a complex of reasons induces the welfare state institution to transform. The key factors that shape the current crisis condition of the welfare state are as follows: 1) political factors (namely, recommendations of influential international expert organizations); 2) changes in the labour market (for instance, the growth of technological unemployment, conditioned by robotization, the mobility of labour resources, the development of freelance, the emergence of flexible business platforms (Amazon, Airbnb, eBay, Uber, and others) etc.); 3) social factors (in particular, a weaker impact of trade unions, individualization of lifestyles, etc.); 4) demographic factors (change in the age structure of the population); 5) gender factors (changes in partner relations and family life forms, etc.). Hence, the stability of welfare states is currently undermined by the consequences of global financial crises, demographic changes, latest tendencies in the labour market, Industry 4.0, change in the family institution, active migration processes and a number of other reasons. On the one hand, these and numerous other reasons contribute to an increase in social spending, and on the other hand - to a higher demand of the population for specific social services. It is obvious that welfare states are not capable of functioning efficiently in the format of classic models as they are overloaded with social services, practical financing of which is aggravated by the budget deficit. Under the influence of the aforementioned and other factors, the welfare state institution is forcedly acquiring new configurations. We should point out that different types of welfare states now show excellent resilience to the effects of globalization and technological change. 
Today, national welfare states have turned to choose the model of adjusting to these challenges under the impact of the aforementioned factors. This choice will determine the future of the welfare state institution. In particular, within the subsidiarity principle some social functions of the state are laid on business and civil society (Хома, 2012: 408). At the legal and regulatory level, certain norms are validated according to which the welfare state institution provides only the basic human needs (infrastructure, subsistence rate, education, health care, etc.), and the remaining issues become the sphere of personal responsibility of each individual (Чиркин, 2002: 9).

In order to maintain the effective functioning of the institution of the welfare state, in our opinion, the following reforms are of significance: 1) gradual departure from the provision of social welfare to able-bodied persons in the direction of creating the broadest possible conditions for their self-realization; 2) state's social investment into the development of human capital; 3) formation of precise understanding of the responsibility for one's own welfare in each working-age individual. These measures are aimed at reducing the load on the welfare state institution in ensuring the person's prosperity. Actually, this means enhancing neoliberal characteristics, which are introduced into the social-democratic (Nordic), conservative (corporatist) model of the welfare state, and upgrading its classic liberal model considerably.

In our view, the modernization of the welfare state requires altering the role of both the state institution and the citizen. The latter should evolve from the object of social care into its active subject. It is impossible to reform the welfare state without any change in the citizens' mind-set, which is primarily manifested in stepping away from paternalism that is more or less deeply rooted in different nations. The study of the role of a state in social protection un- der the increasing influence of globalization and other latest challenges leads us to realize that currently the promising vision of the welfare state is the one that activates a person to provide his or her own personal prosperity, first and foremost. Thus, the problem of a change in the configuration of social policy should be viewed in conjunction with the issues of values, which have to be reinforced in citizens in order to apparently transit to a new social contract.

We aim to argue that the deconstruction of the institution of the welfare state is conditioned by a system of factors, among which an important place is occupied by economic globalization and the Fourth Industrial Revolution. In our study, we turn to the scientific achievements of the authors who initiated one or another aspect of the problem of the welfare state deconstruction. Specifically, the effect of economic globalization on the welfare state was analyzed by A. Atkinson (Atkinson, 2002), S. Berger (Berger, 2000), B. Burgoon (Burgoon, 2001), F. G. Castles (Castles 2004), G. Esping-Andersen (Esping-Andersen 1996), G. Garrett (Garrett, 1998), P. Genschel (Genschel, 2004), W. Korpi (Korpi, 2003), H. Milner (Milner, 2019), P. Pierson (Pierson, 2001), N. Potrafke (Potrafke, 2018), F. W. Scharpf (Scharpf, 1991), R. Wade (Wade, 1996), etc. Certain aspects of the influence of new technologies on the welfare state were studied by Becker S. (Becker, 2019), Blix M. (Blix, 2017), Degryse C. (Degryse, 2016), Ford M. (Ford, 2015), Greve B. (Greve, 2017), Kapeliushnikov R. (Kapeliushnikov, 2019), Lowrey A. (Lowrey, 2018), Summers L. H. (Summers, 2013), etc.

\section{GLOBALIZATION FACTOR OF WELFARE STATE MODERNISATION}

Since the last quarter of the 20th century, the welfare state institution has started functioning in a new global economic en- 
vironment. This process is accompanied by deep institutional transformations. Hence, the interpretation of the reasons for welfare state crisis in the politological discourse is most frequently centred on the factor of economic globalization.

With regard to the fact of the actual influence of economic globalization on the welfare state, there is uncompromising scientific consensus achieved on the matter. Simultaneously, the nature and consequences of this impact have not been specified in detail yet, which causes debates and appearance of various conceptual approaches. Three perspective scenarios have been presented in the scientific discourse:

- negative perspective: the institutional capacity of the welfare state institution is decisively undermined by economic globalization (Castles 2004); national states lose their autonomy of social welfare policies under conditions of global economy (Brady et al., 2005), and there are recommendations of international expert organizations. As in the epoch of economic globalization domestic economies are open to international markets, governments have to adapt to the imperatives of global competition by means of austere fiscal policy, which induces reduction in social welfare programs (Genschel, 2004). Despite evident advantages, the economic openness has resulted in cutting the finances for social sphere (Burgoon, 2001; Garrett, 1998). This approach is currently dominating in the politological discourse;

- sceptical perspective: economic globalization has either insignificant or minimal impact on the welfare state institution (Atkinson, 2002; Kittel \& Winner, 2005; Wade, 1996). There is neither theoretical reason nor empirical evidence to prove categorically that the autonomy of national states' social policy is affected by the increasing economic globaliza- tion (Genschel, 2004). The supporters of this approach believe that various domestic factors, including social and political institutions, historical legacy, etc., still minimise the negative effect of economic globalization on domestic social policy (Berger, 2000). Social policy is still shaped within domestic policy of each country, instead of being completely determined by the leading globalization actors (Pierson, 2001). Therefore, the sceptical perspective claims that welfare states are currently rather resilient to the impact of economic globalization, so the possibility of maintaining and enhancing the welfare state with the consideration of dynamic processes of economic globalization should not be neglected (Brady et al., 2005). That approach was developed on the basis of several empirical studies, the results of which demonstrated that economic globalization does influence the welfare state functioning, but is not determinant (Atkinson, 2002);

- positive perspective: economic globalization and the welfare state are compatible and mutually reinforcing; economic globalization broadens the welfare state (Garrett \& Mitchell, 2001; Rieger \& Leibfried, 2003). Economic openness increases social spending considerably, in consequence the welfare state has the prospect of strengthening.

According to W. Korpi (Korpi, 2003), the pronounced welfare state crisis results from economic globalization, as the latter induces considerable changes in income distribution and increased international tax competition, etc. H. Milner believes that a traditional welfare state does not suggest any efficient mechanisms of responding to numerous social challenges under conditions of economic globalization (Milner, 2019). Numerous researchers explain the rise in income inequality by the conse- 
quences of economic globalization (Bergh \& Nilsson, 2010a; Bergh \& Nilsson, 2010b; Dorn, et al. 2018; Dorn \& Schinke, 2018; Gozgor \& Ranjan, 2017; Lang \& Tavares, 2018). While analysing the effect of economic globalization on social sphere, $\mathrm{N}$. Potrafke concluded that globalization enhances income inequality (Potrafke, 2018). Consequently, political science pays attention first and foremost to the critical analysis of the influence of economic globalization on the welfare state institution. However, many urgent issues are currently not covered by research; for instance, do specific domestic social programs reduce inequality problems caused by globalization?

We adhere to the opinion that, irrespective of evident advantages, economic globalization in its neoliberal form does not promote the functioning of classic models of the welfare state, which, in their turn, are not capable of adequate response to challenges, caused by globalization. It is noteworthy that the issue in what way economic globalization impacts the welfare state remains unclear. Does the fact that countries which entered global competition, forcing governments to economize by cutting social benefits, undermine the social protection? Conversely, economic globalization may have a potential to expand welfare, since citizens, fearing globalization consequences, put pressure on their governments with the demand to create more reliable social buffers. While these and many other questions are yet to be answered, economic globalization is more frequently considered in the politological discourse to be the reason of deformation of classic welfare state models and a threat to the perspective of the very existence of the welfare state institution.

There seem to be reasonable opinions stating that regardless of social character of many countries, the increasing competition between them leads to the rise in poverty, unemployment, occurrence of novel forms of injustice during income distribution. Reductions in welfare expenditure due to economic globalization have resulted in various restrictions on exercising social rights.

The politological discourse is dominated by the opinions that the start of economic globalization ended the relatively stable phase of welfare state functioning. Production is actively being transferred to places with low wages, workplaces are automated with robotic technologies, retirement age is increased, etc. A quarter of a century ago $\mathrm{G}$. Esping-Andersen argued that globalization had limited domestic policy choices and that states had become highly dependent on international trade, finance, and capital movements (Esping-Andersen, 1996). F. W. Scharpf points out that globalization activated global competition, since large capital owners leave the countries with high tax rates for those with much lower ones (Scharpf, 1991). Thus, it results in a decrease in state budget replenishment and the policy of economy in terms of social sphere. According to this approach, economic globalization ruins the welfare state. Hence, it is important to know in which way social policy can withstand structural changes, as most countries have already faced the problem of inefficient classic scheme of social protection.

Economic globalization promoted the affirmation of the approach, by which the aforementioned social expenses impede the perspective of further economic growth. As a result, the welfare state model should be reviewed. The neoliberal approach, claiming the need to decrease social spending, has become firmly established. Countries started active restructuring in order to restore economic growth and simultaneously took measures aimed at cutting social expenditure. At the same time, cases of many countries demonstrate that governmental spending on social sphere was not actually 
cut; on the contrary, it grew. This phenomenon is conditioned, first of all, by changes in the demographic structure.

We agree with the opinion of the researchers who studied the level of the influence of economic globalization on the welfare state and deduced that the impact depended on a specific model of the welfare state. As claimed by American scientists T. K. Kim and K. Zurlo, economic globalization has negative effect on Nordic (social-democratic) model, whereas this mutual interconnection is not too evident in terms of liberal and conservative models (Kim \& Zurlo, 2009: 130). Economic globalization forces the most generous welfare states (the ones that introduce the Nordic model) to reduce (Brady, et al. 2005: 924).

In the context of economic globalization, governments tend to market the institution of the welfare state. These processes originated in the 1990s (Salamon, 1993: 16). Since then, the presence of private social service providers, the influence of market ideas, logic and mechanisms in the provision of public social services have been growing. The tendency to marketize the social state is especially manifested in the states with the liberal model: private providers of social services dominate in the employability of unemployed persons, in eldercare; the number of medical services provided by non-governmental entities is growing, etc.

On the one hand, countries apparently should meet the globalization requirements taking into account the positions of international organizations, transnational corporations, etc. On the other hand, countries face the challenge of ensuring specific welfare standards for their citizens, protecting them from losses related to the adaptation of the country to the global market.

We adhere to the research position that economic globalization is both a challenge and a chance, a perspective for the welfare state institution. We assume that economic globalization influences the welfare state institution by different scenarios in different countries. The scenario is dependent on the type of the welfare state, the model of social policy introduced by a specific country, the level of paternalism of the population, etc. For instance, some countries cut social spending in order to adapt to the imperatives of global competition under globalization, while others increase it to overcome accumulating social and economic problems, conditioned by globalization.

Although economic globalization reduces the autonomy of national states in taking decisions in social sphere and promotes cutbacks in social spending, the peculiarities of national states also influence the rate and scope of these processes. In our opinion, the rate of economic globalization impact on the welfare state is greatly dependent on the position of these national states, first of all, on their willingness to adapt the domestic system of social protection to the requirements of economic globalization.

As economic globalization is the reality, which the national states cannot stand up against, it is reasonable to develop maximally efficient instruments to prevent progressing social problems. The following mechanisms of the so-called active social protection are usually referred to such instruments: stimulating the person's activity in the labour market, restricting passive expenditures, etc. Latest global tendencies demonstrate the direction of reforming classic welfare state models into the model of a service state which guarantees the most relevant social rights. It is apparent that under economic globalization an important task of the modern state is to ensure maximally favourable conditions for personal fulfilment, which would result in reducing the burden on the welfare state institution in part of ensuring personal welfare. 


\section{TECHNOLOGICAL FACTOR OF DECONSTRUCTION OF THE WELFARE STATE}

Advanced technology is mostly a good thing and a road to progress. On all the historical stages they determined economic and social development of countries, promoted expansion of democracy area, produced civil and political activity, etc. Artificial intelligence and computer algorithms replace humans in implementing industrial tasks with ever increasing frequency. In the nearest future, the basis of functioning of the economy of developed countries will be computer-assisted education, Big Data, 3D-printing, nanotechnologies, etc. Artificial intelligence, robotechnics takes over the performance of tasks that used to be designed for humans. It is expected that such novel elaborations as self-driven vehicles will cause the liquidation of thousands of working places. A. Lowrey figuratively called this process "robot apocalypse" (Lowrey, 2018).

Even though the state institution has played a relevant role in financing novel cost-intensive technologies, since the 1970s, the latter have been one of the factors of promoting the financial inequality. It creates a threat of escalation in social tension. The questions arise: in which way will advanced technologies impact the person's welfare level, and as a consequence - the whole perspective of the welfare state institution? What are possible risks for the welfare state, which are conditioned by technological progress? It is evident that proper attention should be paid to the increasing role of technologies, as they are capable of changing relations between people and institutions in a way, which will enhance current inequalities rather than mitigate them. The impact of technologies cannot be ignored, as in perspective they will determine the functioning of social sphere.

Researchers differ in their evaluations of the degree of impact, exerted by technological progress, and digitalisation on the welfare state. Technological innovations transform the employment structure and other spheres that are related to social policy of the state substantially. It is beyond any reasonable doubt that technological progress will have constructive consequences, but some fear that it will result in state budget deficit due to suppression of tax liabilities from salaries, etc. There is an issue of urgency of reforming the welfare state institution in response to technological revolution. Here we can see the whole range of suggested reform scenarios, for instance, the introduction of tax on robotechnics (as suggested by B. Gates) (Shiller, 2017), the introduction of universal basic income (Ford, 2015), etc.

Technological progress constitutes a probable threat to the labour market as well. The most common professions are already under the threat of extinction; the middle class will soon face the same processes. Novel technologies will reduce the demand for "blue colour" and "grey colour" in the professional hierarchy'. Artificial intelligence is likely to push some non-manual workers out of their jobs as well. Let us recollect the experiment, conducted by Financial Times in 2016, as an argument: a specialized journalist and Emma programme simultaneously received a task to prepare a text about unemployment rate in Great Britain, and the editor-in-chief had to ascertain the authorship of each text. The programme completed its work in 12 minutes, but the text was

\footnotetext{
${ }^{1}$ For instance, for three decades (1989 - the first experiment in Paris) many cities (Glasgow, Dubai, Sidney, Istanbul, and others) have been introducing unmanned metro (completely or on specific lines), where an operator's cabin is not even envisaged. Self-driving buses run in Paris, Stockholm, Tallinn and other cities. The first self-driving cars (robocars) are becoming popular. It helps improve the safety of transportation, since one of the dominant reasons for accidents is a human factor.
} 
overloaded with figures, and the language of narration was dry and sometimes unclear. However, it was the programme, not the journalist that predicted the impact of Brexit on the unemployment rate in the country. Thus, it is possible that in a race with machines, the latter may soon defeat humans (Brynjolfsson \& McAfee/ 2014). In his study called Rise of the Robots: Technology and the Threat of a Jobless Future (Ford, 2015), M. Ford notes that in relatively recent history machines have been instruments in human hands, and now they push out and replace an increasing number of specialists. It is evident that business learned how to achieve much higher efficiency using considerably fewer employees.

Technological innovations lead us to the fact of a gradual escalation of problems in the labour market. The researchers voice their forecast about the harmful effect of Industry 4.0 on perspectives of the welfare state (Kapeliushnikov, 2019: 88). Although technological progress provides considerable advantages, a great number of specialists, who have recently been in demand, will be "pushed" into the marginalised dimension. Temporary workers who are doing urgent work, become susceptible to losing a job, as social protection is not applied to them either fully or even partially. There is an already obvious problem of social protection for those who do virtualised labour activity on the Internet, employees of network online structures, etc. Different forms of inequality will be aggravated under such circumstances.

This situation will develop into intense competition in the labour market, increased financial inequality, profound polarization of labour force. A relatively stable social structure will be replaced by the unstable one: a larger part of working-age population will be in the risk zone due to a gradual disappearance of their workplaces. Enhanced differences in income will imminently generate the rise in governmental spending on social support for the needy. At the same instant, the reduction of employment will decrease tax liabilities to the budget, and in consequence, the welfare state institution will be incapable to fulfil its obligations. The fact that technological revolution is continuous and escalatory should be taken into consideration. Accordingly, its results will determine the content of social policy even more (Degryse, 2016), and under high technological unemployment the welfare state institution (regardless of its model) will be incapable of assisting the needy (Frey \& Osborne, 2013).

It is noteworthy that the topic of technological unemployment is not new, as it was raised several times (although on a smaller scale): at the beginning of the $19^{\text {th }}$ century (during industrialization, for the first time in Great Britain); in the 1960s (it was provoked by the fear of automation); between the 1980s and 1990s (computer revolution) (Rifkin, 1995). However, the forecast of the so-called technological alarmists was not confirmed, and the society started to forget about the threat of technological unemployment for some time. Let us consider an example: in 1900 the share of US population, working in agriculture, was $38 \%$, and the share of factory employees $-25 \%$. Today these are $1.5 \%$ and $7.9 \%$ respectively. For the time being, it has not caused destructive social consequences, because the losses were compensated with the growth in other branches of industry and new jobs.

However, robotechnics seems to be replacing and crowding out employees at a far quicker rate than domestic economies and social sphere are able to react to it (Weller, 2016). American researchers assessed that in the nearest future technologies would replace $45 \%$ of jobs, and that by 2030 about $50 \%$ of jobs would be automated (Chui, et al. 2015). In the era of autopilots, smart infrastructure, etc. a human factor will be both more expensive and less safe. 
Smart-contracts and improved logistics will completely automate the production of goods; the current number of people who are employed in the production of public goods will not be required. This is manifested even today. For instance, in the sphere of law an abundance of bots implement basic legal tasks.

The study of British futurologists C. B. Frey and M. A. Osborne (Frey \& Osborne, 2017) demonstrates that over $47 \%$ out of the total number of the employed are in the group of increased risk and are likely to be automated in the next decade; 2 billion jobs will disappear by 2030. As for the developed countries, the aforementioned researchers predict with a high probability the disappearance of the demand for cashiers, packers, telemarketers, field judges and referees, insurance agents, seamstresses, watch makers, loaders, tax consultants, data processing operators, librarians, brokers, credit experts, accountants and auditors, waiters, bus drivers, guards, street cleaners, and others by 2033.

When futurological trends are summarized, the most frequently voiced predictions are as follows: 1) "disappearance" of about half of current professions within the nearest decade (Frey \& Osborne, 2013); 2) the velocity of technological changes will be so high that employees will not be physically capable of retraining for new professions, and as a result will become unemployed (Ford, 2015); 3) one should be ready even for the disappearance of highly qualified jobs, inasmuch as novel technologies will take over intellectual functions, which have been a human prerogative (Brynjolfsson \& McAfee, 2014). The existential problem may arise even from the issue of reasonable filling in one's leisure time and finding finances to exist under conditions when the notion of work in its traditional sense will become a thing of the past, and a considerable amount of work will be done by artificial intelligence, not by a human (Summers, 2013).

The issue of readiness of traditional industries and institutions to digitalisation, the possibilities and threats of artificial intelligence were in the centre of attention of the World Economic Forum in Davos in 2019 (the topic of the event - Globalisation 4.0: Shaping a New Global Architecture in the Age of the Fourth Industrial Revolution). In general, since 2011 the topic of Industry 4.0 has become a major trend of political-economic discussions in the leading countries of the world, attracting attention to the need of coordinated state initiatives in terms of mobilisation of all the national resources for the purpose of accelerating technological changes with consideration of their possible impacts.

If many workplaces, which made their contributions to the state mandatory social insurance, are liquidated due to technologization, the financial foundation of many welfare states will become imminently weaker. In addition, taking competition into account, the excess of labour force will cause a reduction in salaries in the sectors where human potential is used.

It is not implausible that similar to globalization, the technological progress and digitalisation will divide human community into winners and losers and in consequence will pose a threat to social peace and cast discredit on the stability and capability of the welfare state institution (Becker, 2019). Technological revolution is assumed to bring prosperity not to society as a whole (inclusive growth ${ }^{2}$ ), but only to the few (exclusive growth).

\footnotetext{
2 "Inclusive growth" refers to economic development, within which possibilities arise for all the strata of the population, material and non-material benefits are fairly distributed in the society for the purpose of increasing its welfare. This is in reference to both the narrowing of a gap between the rich and the poor, equal conditions of receiving education, efficient health care and possibilities of security.
} 
B. Greve, a Danish researcher, gives a negative response to the question about the readiness of welfare states to react adequately to the challenges which were caused by the Fourth Industrial Revolution. As welfare states are financed with taxes, the expansion of platform economy, non-standard workplaces, and self-employment will destroy the taxation foundation on which the social security funding relies (Greve, 2017). One can agree with this assumption to some extent, taking into consideration the following: 1) although technological innovations promote the emergence of new highly technological workplaces, there are no sufficient arguments to prove that it will compensate for the loss of workplaces which were liquidated while introducing novel technological elaborations; 2) at present there are four employees per one pensioner in Europe; in 2025 there will be three, and in 2050 - two employees per one pensioner. This will determine the state budget replenishment and further capability of the welfare state institution to fulfil its functions.

It is noteworthy that the topic of the impact of technological progress on employment rate and welfare state is debateable. There are both techno-optimists and techno-pessimists (they were referred to as techno-alarmists above) among researchers. In their arguments, everybody mainly addresses the factor of the technological progress impact on the employment of the population. For instance, in 2011 E. Brynjolfsson and A. McAfee substantiated the technological explanation for the long-term high unemployment rate in the USA (Brynjolfsson \& McAfee, 2011). However, as of October 2019, the unemployment rate decreased considerably - down to $3.6 \%$ (this is the lowest index in the USA since 1969). And this is regardless of the fact that within the first decade of the $21^{\text {st }}$ century, the automation of production liquidated about 8 million workplaces in the USA (Lanchester, 2019).
We traced the unemployment rate in the countries with the highest indices of robotization (at present these are South Korea, Singapore, Germany, Japan, Sweden, etc.). As of September 2019, the unemployment rate in South Korea, Singapore and Japan was $2.2 \%$ in each, in Germany $-3.1 \%$, and in Sweden $-7.4 \%$. The differences in unemployment rates in the mentioned countries do not allow for unambiguous conclusion about the pronounced constructive or destructive impact of robotization on the employment rate. As applied to Sweden, it should be highlighted that here the welfare state faces both the challenges of the impact of technologies and immigration. We share the opinion of the Swedish researcher M. Blix (Blix, 2017) that, in case of this, Nordic welfare state novel technologies enhance the polarisation of working places and salaries, etc., rather than condition it. Apparently, a substantial complex of factors impacts employment indices and robotization is not the determinant therein yet, but may become one in the nearest perspective.

Obviously, the transformation of the welfare state in accordance with the new realities of the digital era requires adequate reactions both at institutional and individual levels. However, the problems, bred by the digital era, should be solved in a way that does not hinder digital growth. It seems reasonable to have first-priority renewal of human capital for management and generation of knowledge, since an innovative state requires specialists who are open to innovations and constant learning. Technological revolution demands that employees should be mobile, flexible, capable of acquiring new competences and adapting to market variability quickly, etc.

It stands to reason that the welfare state is often called "a digital welfare state" in Western democracies. This leads us to understanding that as technological progress and digitalisation are inevitable, the welfare 
state institution should adapt, finding new sources of state budget replenishment, establishing the culture of working-age individual's activism in ensuring his or her own prosperity, etc.

From our standpoint, technological progress opens new opportunities, strengthens the available ones, and causes new risks for the welfare state and stability of state finances. If in the nearest future the technological breakthrough triggers the rise of unemployment and contraction of the payroll deductions to the budget, powerful economic, social and political upheavals are to be expected. These may be prevented before they arise by means of the following actions: revision of the taxation system (imposing taxes on technological innovations and income of citizens, which were obtained from the platform economy), introduction of innovations in educational policy, formation of the population's willingness to continuous study and retraining, etc.

\section{PLATFORM ECONOMY AS MANIFESTATION OF GLOBALIZATION AND TECHNOLOGICAL INFLUENCE ON THE WELFARE STATE}

Rapidly growing platform economy is exerting its pressure on the welfare state. The business model of the platform economy blurs the traditional definitions of the welfare state (Eichhorst \& Rinne, 2017). The development of such commercial virtual structures is transforming common models of social and labour relations because this is a specific space in which companies are virtual, an employer is not personified, and a worker is officially self-employed and may live anywhere on the planet.

These processes relate to the problem of imposing income taxes, and consequently - to state budget replenishment. There is a profound problem of inaccurate taxation of income, obtained from the functioning of the platform economy. For instance, questions arise about income taxes for the owners of property who rent it out (via such online services as Airbnb, Booking.com, Agoda and others) ${ }^{3}$, as well as services like TaskRabbit and Zaarly (mobile job markets for those willing to do some work, mainly household tasks), DogVacay (taking care of animals while their owners are absent; this is an alternative to rather expensive hotels for animals), RelayRides (a possibility to rent a vehicle avoiding renting companies), etc. Sharing economy is established as a new type of culture and economic business model, by which people use technologies and online platforms to offer their assets, which they do not use during specific periods. The development of this type of economy raises the question about imposing taxes on the obtained income to replenish state budgets, and thus about the possibility for the state to fulfil its social functions. There are also problems with taxation (or rather tax avoidance) of freelancers, though many countries have determined legal norms of their registration as private entrepreneurs, and as a result - the norms of taxation for them.

It seems that technological progress should not be viewed from one standpoint only - from the standpoint of risks for the welfare state. To our way of thinking, it may

\footnotetext{
${ }^{3}$ It has triggered protests of the owners of hotels and other registered property, especially in large cities, visited by many tourists, where legal market of rented property suffers losses due to cheaper "accommodation from the locals". The report of the US National Bureau of Economic Research highlights: the profit of hotels in American cities would be higher, if services like Airbnb did not exist at all (Farronato \& Fradkin, 2018). There are active counteractions to online accommodation services in a number of tourist cities. For example, in June 2018 the authorities of Palma de Mallorca, a Spanish city, took a radical decision about complete prohibition of Airbnb services.
} 
also promote cutting social expenditures, which is obviously positive. For instance, technological innovations facilitate care for the elderly and sick people, available novel medical technologies enable quick diagnostics and recovery, etc. Therefore, if it is possible to increase taxes on income from robotization, it may enhance the stability of state finances (Becker, 2019). Additional inputs may promote the payments funding that is related to the aging of the population, migration, etc. Thus, it would be reasonable for governments to review the financial basis of the welfare state as soon as possible. In all other cases, even the richest countries will face noticeable budget deficit.

The transition from the welfare state to the innovation state is expected under conditions of technological process (Rodrik, 2015). Today, the state institution should direct the economy towards new techno-economic paradigms; states should be focused not only on minimizing failures, but on maximizing innovations (Mazzucato, 2015). The point at issue is the perspective of the model of the innovation state, which acts proactively.

\section{CONCLUSIONS}

The deconstruction of the welfare state is a reaction to its crisis. Prevalent global tendencies are: the reduction in welfare payments, the decrease in social services (austerity policy), the rise of the retirement age, etc. Nowadays all classic models of the welfare state are under great pressure, cutting social expenditure, and getting transformed under the impact of a complex of factors:

- the Nordic model of the welfare state mostly loses stability under conditions of the latest globalization and technological challenges. This became especially pronounced after the beginning of the pan-European migration crisis, when public opinion began to radicalize under the influence of the wave of refugees. Hence, in the countries where this model is embedded, a favourable climate for populism is formed; the case of Sweden is a bright illustration of this;

- the neoliberal model of the welfare state becomes even more focused on stimulating individual activity, increasing personal responsibility, investing in personal social capital in order to further reduce the financial burden on the institution of the welfare state. The role of extra-budgetary financing of the social sphere is growing. The disciplinary basis of such a model of the welfare state is strengthened. The institution of the welfare state begins being marketed;

- the conservative model of the welfare state is the slowest to adapt to dynamic changes of the socio-economic environment. Traditional social insurance programs are reduced, numerous incentives to work are introduced in combination with the expansion of social investment policy. Today, this model is actively contributed by neoliberal characteristics, processes of activation in the labour market are unfolding, there is a search for a balance between work and family, and so on.

Despite conceptual differences, all models have a similar trajectory of reforms - to activate a working-age person, to build the state of social investments. There are many facilitating factors, economic globalization and technological revolution among them, first and foremost.

Economic globalization has decreased the capability of national states to independently develop and implement domestic social policy, and has set as the priority of the welfare state institution to ensure maximally favourable conditions for self-fulfilment of everyone with the purpose of reducing the pressure on the state in part of ensuring welfare of a person. Nevertheless, in our view, globalization is a stimulus for 
further evolution of the welfare state institution for the latter to come out of a prolonged stagnation and preserve itself as a political institution, albeit in the upgraded model. Thus, in our assessment globalization is both a challenge and a chance, a perspective for the welfare state institution.

The Fourth Industrial Revolution refreshed the issue of welfare, social guarantees and those risks for the welfare state institution which are caused and will be further enhanced by technological progress. In the nearest future it will be technologies that determine the functioning of the welfare state taking into consideration the fact that they will transform the employment structure and other spheres related to state social policy considerably. The expansion of platform economy, non-standard workplaces, self-employment and freelance is already destroying the taxation foundation, on which social protection depends. Technological development may condition the rise in unemployment, and as a result, the cutbacks of payroll deductions to the budget for state mandatory social insurance. Weakening of the financial basis of many welfare states will inevitably cause the aggravation of social and political tensions. These may be prevented by the revision of taxation system, the introduction of innovations in the educational policy, the formation of the population's willingness to continuous study and retraining, etc.

Concurrently, it is unreasonable to view technological progress and globalization only from the standpoint of risks for the welfare state, because it is capable of cutting social expenditures as well, for instance, due to the progress in medical services. Therefore, as, similarly to economic globalization, technological progress and digitalisation are imminent, the welfare state institution should adapt, finding new sources of state budget replenishment, forming the culture of labour activism of a working-age person to ensure his or her prosperity.
Getting modernized under the impact of economic globalization and technological progress, the welfare state is likely to be in operation, but on condition of reloading its form and content. It may be possible to solve the problems in social sphere, which were caused by economic globalization, only by way of considerable change in priorities and instruments of the welfare state.

A review of the sources available on the research topic, as well as our own analysis, have led to the following conclusions:

The welfare state has faced a complex of challenges: some of them are exogenous and are conditioned by strengthening of international interdependence; others are endogenous and are conditioned by internal social demographic, economic and political factors. Economic globalization and technological progress are designated as decisive factors conditioning the deconstruction of the welfare state. The deconstruction of the welfare state is a reaction to its crisis. Common global tendencies are: the decrease in welfare benefits, the cutbacks in social services (austerity policy), the rise of the retirement age, etc. All classic models of the welfare state are currently under great pressure, while cutting social spending and getting transformed under the influence of a complex of factors. Being modernized under the sway of economic globalization and technological progress, the welfare state is probable to function, but on condition of resetting its form and content. The problems in social sphere, which were caused by economic globalization, are possible to solve only via a considerable change in the priorities and instruments of the welfare state.

\section{REFERENCES}

Atkinson, A. (2002). Globalisation and the European welfare state at the opening and the closing of the twentieth century. In H. Kierzkowski (Ed.), Europe and Globalisation. New York: Palgrave-MacMillan. 
Becker, S. (2019). Digital structural change and the welfare state in the 21st century. Frankfurt am Main: Deutsche Bank Research.

Berger, S. (2000). Globalisation and politics. Annual Review of Political Science, 3, 43-62. https://doi. org/10.1146/annurev.polisci.3.1.43

Bergh, A., \& Nilsson, T. (2010a). Do liberalization and globalisation increase income inequality?. European Journal of Political Economy, 26(4), 488-505. https://doi.org/10.1016/j.ejpoleco.2010.03.002

Bergh, A., \& Nilsson, T. (2010b). Good for living? On the relationship between globalization and life expectancy. World Development, 38(9), 1191-1203. https://doi.org/10.1016/j.worlddev.2010.02.020

Blix, M. (2017). Digitalization, immigration and the welfare state. Cheltenham: Edward Elgar Publishing.

Brady, D., Beckfield, J., \& Seeleib-Kaiser, M. (2005). Economic globalisation and the welfare state in affluent democracies, 1975-2001. American Sociological Review, 70(6), 921-948. https://doi. org/10.1177/000312240507000603

Brynjolfsson, E., \& McAfee, A. (2011). Race against the machines: How the digital revolution is accelerating innovation, driving productivity, and irreversibly transforming employment and the economy. Lexington, MA: Digital Frontier Press.

Brynjolfsson, E., \& McAfee, A. (2014). The second machine age: Work, progress, and prosperity in a time of brilliant technologies. New York: WW Norton \& Company.

Burgoon, B. (2001). Globalisation and welfare compensation: Disentangling the ties that bind. International Organization, 55(3), 509-551. https:// doi.org/10.1162/00208180152507542

Castles, F. G. (2004). The future of the welfare state: Crisis myths and crisis realities. Oxford: Oxford University Press.

Chui, M., Manyika, J., \& Miremadi, M. (2015). Four fundamentals of workplace automation. Available at https://www.mckinsey.com/business-functions/digital-mckinsey/our-insights/ four-fundamentals-of-workplace-automation

Чиркин, В. Е. (2002). Общечеловеческие ценности и современное государство. Государство и право, 2, 5-13.

Degryse, C. (2016). Digitalisation of the economy and its impact on labour markets. Brussels: ETUI.

Devlin, S. (2017). (In)Equality in the digital society. Workshop summary. London: Fried-
rich-Ebert-Stiftung London Office, The New Economics Foundation.

Dorn, F., Fuest, C., \& Potrafke, N. (2018). Globalisation and income inequality revisited. CESifo Working Paper, 6859.

Dorn, F., \& Schinke, C. (2018). Top income shares in OECD Countries: The role of government ideology and globalisation. World Economy, 41(9), 2491-2527. https://doi.org/10.1111/twec.12638

Eichhorst, W., \& Rinne, U. (2017). Digital Challenges for the Welfare State. IZA Policy Paper No. 134. Bonn: Institute of Labor Economics.

Esping-Andersen, G. (1996). After the golden age? Welfare state dilemmas in a global economy. In G. Esping-Andersen (Ed.), Welfare slacks in transition. London: Sage Publications.

Farronato, C., \& Fradkin, A. (2018). The welfare effects of peer entry in the accommodation market: The case of Airbnb. NBER Working Paper No. 24361. Available at https://www.nber.org/ papers/w24361.pdf

Ford, M. (2015). Rise of the robots: Technology and the threat of a jobless future. New York: Basic Books.

Frey, C. B., \& Osborne, M. A. (2013). The future of employment: How susceptible are jobs to computerisation?. Oxford Martin School Working Paper. Available at https://www.oxfordmartin. ox.ac.uk/downloads/academic/future-of-employment.pdf

Frey, C. B., \& Osborne, M. A. (2017). The future of employment: How susceptible are jobs to computerisation?. Technological Forecasting and Social Change, 114, 254-280. https://doi. org $/ 10.1016 / j$.techfore.2016.08.019

Garrett, G. (1998). Global markets and national politics: Collision course or virtuous circle?. International Organization, 52(4), 787-824. https:// doi.org/10.1162/002081898550752

Garrett, G., \& Mitchell, D. (2001). Globalisation, government spending and taxation in the OECD. European Journal of Political Research, 39(2), 145-177.https://doi.org/10.1111/1475-6765.00573

Genschel, P. (2004). Globalisation and the welfare state: A retrospective. Journal of European Public Policy, 11(4), 613-636. https://doi. org/10.1080/1350176042000248052

Gozgor, G., \& Ranjan, P. (2017). Globalisation, inequality, and redistribution: Theory and evidence. World Economy, 40(12), 2704-2751. https://doi.org/10.1111/twec.12518

Greve, B. (2017). Technology and the future of work The impact on labour markets and welfare states. Cheltenham: Edward Elgar. 
Hemerijck, A. (Ed.). (2017). The uses of social investment. Oxford: Oxford University Press.

Хома, Н. М. (2012). Моделі соціальної держави: Світовий та український досвід. Київ: Юридична думка.

Kapeliushnikov, R. (2019). The phantom of technological unemployment. Russian Journal of Economics, 5(1), 88-116. https://doi.org/10.32609/j. ruje.5.35507

Kelly, G. (28 Oct 2018). We can't all be winners as a new welfare state emerges. The Guardian.

Kim, T. K., \& Zurlo, K. (2009). How does economic globalisation affect the welfare state? Focusing on the mediating effect of welfare regimes. The International Journal of Social Welfare, 18(2), 130-141. https://doi.org/10.1111/j.14682397.2008.00575.x

Kittel, B., Winner, H. (2005). How reliable is pooled analysis in political economy? The globalization-welfare state nexus revisited. European Journal of Political Research, 44(2), 269-293. https://doi.org/10.1111/j.1475-6765.2005.00228.x

Korpi, W. (2003). Welfare-state regress in Western Europe: Politics, institutions, globalisation and Europeanization. Annual Review of Sociology, 29, 589-609. https://doi.org/10.1146/annurev. soc.29.010202.095943

Lanchester, J. (16 Jan 2019). The next industrial revolution is coming. Here's how we can ensure equality. Time.

Lang, V., \& Tavares, M. (2018). The distribution of gains from globalisation. IMF Working Paper, 18/54.

Lowrey, A. (2018). Give people money: How a universal basic income would end poverty, revolutionize work, and remake the world. New York: Crown Publishing.

Mazzucato, M. (2015). The innovative state. Foreign Affairs, 2. Available at https://www.foreignaffairs.com/articles/americas/2014-12-15/ innovative-state

Milner,H. V. (2019). Globalisation, populism and the decline of the welfare state. Available at https:// www.iiss.org/blogs/survival-blog/2019/02/globalisation-populism-and-the-decline-of-the-welfare-state

Pierson, P. (2001). The new politics of the welfare state. Oxford: Oxford University Press.

Potrafke, N. (2018). The globalization-welfare state nexus Evidence from Asia. Ifo Working Paper, 272. Available at https://www.ifo.de/DocDL/wp2018-272-potrafke-welfare-asia.pdf

Rieger, E., \& Leibfried, S. (2003). Limits to globalisation: Welfare states and the world economy. Malden: Polity Press.

Rifkin, J. (1995). The end of work: The decline of the global labor force and the dawn of the post-market era. New York: Putnam.

Rodrik, D. (2015). From welfare state to innovation state. Available at https://www.project-syndicate.org/commentary/labor-saving-technology-by-dani-rodrik-2015-01

Salamon,L. M. (1993). The marketization of welfare: Changing non-profit and for-profit roles in the American welfare state. Social Service Review, 67(1), 16-39. https://doi.org/10.1086/603963

Scharpf, F. W. (1991). Crisis and choice in European social democracy. Ithaca, NY: Cornell University Press.

Shiller, R. (22 Mar 2017). Why robots should be taxed if they take people's jobs. The Guardian.

Summers, L. H. (2013). Economic possibilities for our children. The 2013 Martin Feldstein Lecture. NBER Reporter, 4. Digital Challenges for the Welfare State.

Wade, R. (1996). Globalisation and its limits: Reports of the death of the national economy are greatly exaggerated. In S. Berger \& R. Dore (Eds.), National Diversity and Global Capitalism. Ithaca, NY: Cornell University Press.

Weller, C. (2016). Giving people free money could be the only solution when robots finally take our jobs. Available at https://www.businessinsider. com/basic-income-could-be-the-only-solutionin-a-robot-economy-2016-4 
Sažetak

\title{
Dekonstrukcija socijalne države: utjecaj globalizacijskih i tehnoloških čimbenika
}

\author{
Nataliya Khoma \\ Ihor Vdovychyn \\ Katedra teorije i povijesti političke znanosti Filozofskog fakulteta \\ Nacionalnog sveučilišta Ivan Franko u Lvivu
}

Lviv, Ukrajina

Cilj rada je istražiti procese dekonstrukcije institucije socijalne države pod utjecajem novih izazova kao što su ekonomska globalizacija i tehnološka revolucija. Rad se temelji na metodološkim alatima neoinstitucionalizma. Utvrđeni su glavni egzogeni i endogeni uzroci krize institucije socijalne države. Ekonomska globalizacija i tehnološki napredak svrstani su među odlučujuće čimbenike koji uzrokuju dekonstrukciju socijalne države. Sve socijalne države, bez obzira na njihov model, sada se reformiraju putem aktiviranja radno sposobnih osoba i stvaranja države socijalnih ulaganja. Primjećuje se da danas konfiguraciju socijalne države određuje njezin fokus na poticanje konkurencije i razvoj samoinicijative stanovnika glede osiguravanja vlastite dobrobiti. Naglašava se da ekonomsku globalizaciju i tehnološki napredak ne treba sagledavati samo kroz rizike za socijalnu državu. Ova su dva čimbenika utvrđena kao poticaji za daljnji razvoj institucije socijalne države kako bi se prevladalo njeno dugotrajnije stagniranje i kako bi se ona sačuvala kao politička institucija, ali u obnovljenom modelu.

Ključne riječi: institucija socijalne države, dekonstrukcija socijalne države, ekonomska globalizacija, platformska ekonomija, tehnološki napredak, Četvrta industrijska revolucija. 